\title{
On the genetic distinctiveness of tailorbirds (Cisticolidae: Orthotomus) from the South-east Asian mainland with the description of a new subspecies
}

Jérôme Fuchs ${ }^{*}$ and Dario Zuccon

\begin{abstract}
Background: The Cambodian Tailorbird (Orthotomus chaktomuk) was one of the most recent major ornithological discoveries in South-east Asia as it originated from lowland seasonally flooded scrub within the densely inhabited floodplain around the Tonle Sap, Mekong and Bassac rivers (Cambodia). The Cambodian Tailorbird is sister to the Dark-necked Tailorbird (O. atrogularis) with very limited genetics and biometric differentiation. Between 2004 and 2012, evidences of a new population of Ashy Tailorbird (O. ruficeps) in SE Cambodia/Vietnam accumulated but no museum specimens were ever reported. The Ashy Tailorbird currently consists of eight subspecies among which the closest geographical populations, O. r. cineraceus (SE Burma to Malay Peninsula, Sumatra, Bangka and Belitung) and O. r. borneoensis (Borneo), are allopatric. Subspecific identification of the Cambodian Ashy Tailorbirds individuals was not possible because of the limited differences in plumage among subspecies.
\end{abstract}

Methods: We inspected the Orthotomus ruficeps specimens housed at the Museum National d'Histoire Naturelle (Paris) and discovered five specimens of O. ruficeps collected by Louis Rodolphe Germain in 'Cochinchina' (corresponding to southern Vietnam) during the nineteenth century. We sequenced one mitochondrial locus and gathered biometric data from these specimens and compared them with other Orthotomus lineages.

Results: The Ashy Tailord population from SE Cambodia and Vietnam is distinct from the two geographically close subspecies O. r. borneoensis (1.7\%) and O. r. cineraceus (1.3\%). O. chaktomuk is nested within O. atrogularis in the mitochondrial gene tree. The SE Cambodia/Vietnam population of $O$. ruficeps is distinct from the two other subspecies in bill shape.

Conclusion: Our study described the biometric and molecular distinctiveness of a recently re-discovered population of Ashy Tailord in SE Cambodia and Vietnam and suggests that this population constitutes an independent evolutionary lineage that we describe here as a new subspecies. The newly described Cambodian Tailorbird is nested within the Dark-necked Tailorbird and the genetic divergence is much lower than initially described (0.4-0.7\% vs $1.1-1.4 \%)$.

Keywords: Orthotomus, Differentiation, Subspecies, Taxonomy

\footnotetext{
*Correspondence: fuchs@mnhn.fr
}

Institut de Systématique, Evolution, Biodiversité UMR7205 CNRS MNHN

UPMC EPHE, Sorbonne Université, Muséum National d'Histoire Naturelle,

CP 51, 57 rue Cuvier, 75231 Paris Cedex 05, France

(C) The Author(s) 2018, corrected publication November 2018. This article is distributed under the terms of the Creative Commons Attribution 4.0 International License (http://creativecommons.org/licenses/by/4.0/), which permits unrestricted use, distribution and reproduction in any medium, provided you give appropriate credit to the original author(s) and the source, provide a link to the Creative Commons license, and indicate if changes were made. The Creative Commons Public Domain Dedication waiver (http://creativecommons.org/publicdomain/zero/1.0/) applies to the data made available in this article, unless otherwise stated. 


\section{Background}

South-east Asia has revealed several spectacular new species to science over the last three decades, mostly from the annamitic chain of Lao RDP and Vietnam, including a forest Bovidae (Saola, Pseudoryx nghetinhensis, Vu et al. 1993), the first representative of Caudata for Laos RDP (Laotriton laoensis, Stuart and Papenfuss 2002), a member of the Diatomyidae (Laonastes aenigmaeus, Jenkins et al. 2005), a lineage of rodents that was presumed to be extinct for the last 11 Myrs, and the Bare-faced Bulbul (Pycnonotus hualon, Woxvold et al. 2009), a highly distinct passerine for which a new genus was recently described (Fuchs et al. 2018).

Hence, it came with great surprise that the most recent major ornithological discovery in South-east Asian mainland, the Cambodian Tailorbird (Orthotomus chaktomuk Mahood et al., 2013), originated from lowland seasonally flooded scrub within the densely inhabited floodplain around the Tonle Sap, Mekong and Bassac rivers in southern Cambodia. This newly described taxon has been shown to be part of the O. atrogularis-O. ruficeps-O. sepium clade (Sheldon et al. 2012; Mahood et al. 2013). The Cambodian Tailorbird was sister to the Dark-necked Tailorbird (O. atrogularis Temminck, 1836), with limited genetic (1.1-1.4\% divergence in the analysed mitochondrial locus, the NADH dehydrogenase II) and biometric (culmen/wing ratio in males) differentiation. Vocalizations and plumage characters appeared to be slightly more divergent from its sister species $O$. atrogularis with the latter being somewhat intermediate between the plumage of $O$. atrogularis ssp. and $O$. ruficeps. The Ashy Tailorbird (Orthotomus ruficeps Lesson, 1830) currently consists of eight subspecies among which only one occurs on South-east Asian mainland, O. r. cineraceus Blyth, 1845 (SE Burma to Malay Peninsula, Sumatra, Bangka and Belitung; Fig. 1) (Dickinson and Christidis 2014). Further widely distributed subspecies occur on Borneo (O. r. borneoensis Salvadori, 1874) and Java (O. r. ruficeps Lesson, 1830). The remaining five subspecies are found in peripheric island of Sumatra $(O$. r. baeus Oberholser, 1912, Nias and Pagi Is.; O. r. concinnus Riley, 1927, Siberut, Sipura Is.), Java (O. r. palliolatus Chasen and Kloss, 1932, Kangean, Karimon Java Is.; O. r. baweanus Hoogerwerf, 1962, Bawean Is.) and Borneo (O. r. cagayanensis Riley, 1935, Cagayan Sulu Is.). Hence, no known populations of $O$. ruficeps were known to be distributed close to the range of O. chaktomuk until 2012 when the Ashy Tailorbird was detected near Kampot and Kep in SE Cambodia (Mahood and Martin 2013; Goes 2013). Further evidences of the occurrence of previously unknown O. ruficeps populations in the Mekong area of Vietnam were suggested by Buckton and Safford (2004) and Robson (2011). The localities where Ashy Tailorbirds were detected in Cambodia are only $20-30 \mathrm{~km}$ from the known populations in Vietnam. Yet, as Mahood and Martin (2013) stated, "Subspecific identification in Cambodia

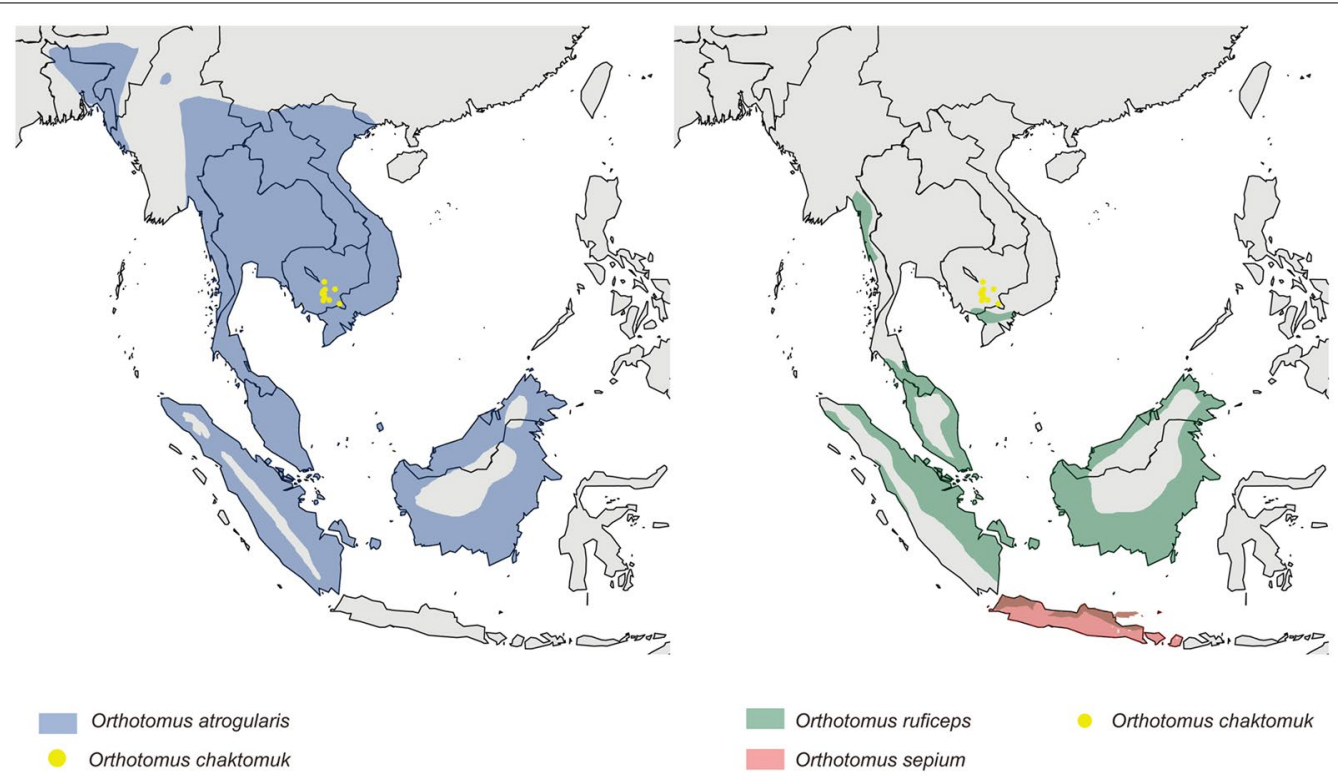

Fig. 1 Distributions of O. atrogularis, O. sepium, O. ruficeps and O. chaktomuk (BirdLife International and NatureServe 2013, excepted O. chaktomuk, Yellow dots). Maps were made using the R (R CoreTeam 2013) libraries maps and mapdata (Becker and Wilks 2013), maptools (Bivand and Lewin-Koh 2014) and scales (Wickham 2014). The distribution map is based on BirdLife International, NatureServe (2013) except for the Cambodia/Vietnam population of O. ruficeps (HBWalive; hbwalive.com) 
is not possible because no specimens of the Mekong delta population have been collected; but due to its geographic isolation it is probable that this population represents an undescribed subspecies." As the Museum National d'Histoire Naturelle, Paris (MNHN) has an extensive collection of specimens from South-east Asia, we decided to inspect the Orthotomus specimens and discovered five specimens (Table 1) of Orthotomus ruficeps collected by Louis Rodolphe Germain, a veterinary surgeon in the French colonial's army during the 1860-1865 period, in 'Cochinchina' (corresponding now to Southern Vietnam). Inspection of the MNHN catalog indicated that one further individual was exchanged with $\mathrm{H}$. von Berlepsch in 1892 and is now cataloged in the Senckenberg Museum (SMF 78404).

We here provide the first biometric data for the Cambodian/Vietnamese populations of O. ruficeps as well as preliminary genetic evidence for its distinctiveness from other Orthotomus populations in South-east Asian mainland. We also included in the genetic analyses three individuals of $O$. atrogularis nitidus Hume, 1874. This mainland subspecies was not included in the genetic analyses of Mahood et al. (2013) for the description of $O$. chaktomuk. Instead, only one individual of O. a. atrogularis from Singapore was included. Yet, several studies now showed that the populations distributed south of the Isthmus of Kra are genetically very differentiated from populations distributed north of the Isthmus (Sheldon et al. 2009) and are even sometimes not directly related (e.g. Fuchs et al. 2015).

\section{Methods}

\section{Molecular data}

We extracted DNA from toe pads of nine specimens housed in the collections of the Muséum National d'Histoire Naturelle, Paris (MNHN, Table 2) using the Qiagen DNA Mini Kit (Qiagen, Inc), following the manufacturer's protocol or the modified protocol described in Zuccon and Ericson (2010) for the toe-pad samples. We obtained complete sequences for the mitochondrial NADH dehydrogenase II (ND2) gene by performing several overlapping PCR (size 200-250 bp) using specific primers designed in this study (Additional file 1: Table S1). The amplification profile was: initial denaturation 5 min at $95^{\circ} \mathrm{C}$, followed by 35-40 cycles of denaturation $30 \mathrm{~s}$ at $95{ }^{\circ} \mathrm{C}$, annealing $30 \mathrm{~s}$ at $57^{\circ} \mathrm{C}$, extension $45 \mathrm{~s}$ at $72{ }^{\circ} \mathrm{C}$, with a final extension of $5 \mathrm{~min}$ at $72{ }^{\circ} \mathrm{C}$. PCR products were cleaned using QIAquick PCR Purification Kit (Qiagen) and run on an ABI Prism 3100 automated DNA sequencer (Perkin-Elmer Applied Biosystems).

Table 1 Details of the six specimens of Orthotomus ruficeps from southern Vietnam (original label mention is Cochinchina) collected by Louis Rodolphe Germain and representing, to our knowledge, the only specimens deposited in natural history museums

\begin{tabular}{llllll}
\hline Collector & Catalog number & Sex & Collection date & Locality & Country \\
\hline Germain L.R. & MNHN ZO 1866-573 & Female & 28 February 1864 & 'Cochinchina' & 'Cochinchina' Vietnam \\
Germain L.R. & MNHN ZO 1882-738 & Male & & 'Cochinchina' Vietnam \\
Germain L.R. & MNHN ZO 1882-739 & Female & 21 April 1865 & 'Cochinchina' & Vietnam \\
Germain L.R. & MNHN ZO 1882-740 & Female & & 'Cochinchina' \\
Germain L.R. & MNHN ZO 1882-742 & Male & 29 February 1864 & 'Cochinchina' \\
Germain L.R. & SMF 78404 & Male & & & Vietnam \\
\hline
\end{tabular}

The specimen in Senckenberg was previously cataloged at MNHN with the number MNHN ZO 1882-741; this specimen was not sequenced

Table 2 Details of the nine specimens of Orthotomus sequenced as part of this study

\begin{tabular}{|c|c|c|c|c|c|}
\hline Species & Collector & Catalog number & Collection date & Locality & Country \\
\hline ruficeps & Germain L.R. & MNHN ZO 1866-573 & 28 February 1864 & 'Cochinchina' & Vietnam \\
\hline ruficeps & Germain L.R. & MNHN ZO 1882-738 & & 'Cochinchina' & Vietnam \\
\hline ruficeps & Germain L.R. & MNHN ZO 1882-739 & 21 April 1865 & 'Cochinchina' & Vietnam \\
\hline ruficeps & Germain L.R. & MNHN ZO 1882-740 & & 'Cochinchina' & Vietnam \\
\hline ruficeps & Germain L.R. & MNHN ZO 1882-742 & 29 February 1864 & 'Cochinchina' & Vietnam \\
\hline atrogularis & Germain L.R & MNHN ZO 1882-728 & 13 April 1867 & 'Saigon, Cochinchina' & Vietnam \\
\hline atrogularis & J. Delacour/P. Jabouille & MNHN ZO 1929-1463 & 27 February 1928 & Phu-Qui & Vietnam \\
\hline atrogularis & J. Delacour/P. Jabouille & MNHN ZO 1939-913 & 25 January 1930 & Hoi-Xuan & Vietnam \\
\hline atrogularis & J Roche/J. Thiney & MNHN ZO 1989-120 & 17 December 1986 & Trang & Thailand \\
\hline
\end{tabular}


Our new sequences were analysed together with all ND2 sequences published by Sheldon et al. (2012), Mahood et al. (2013) and Lim et al. (2014). Newly generated sequences have been deposited in Genbank (Accession numbers: MH507590-MH507598).

\section{Analyses}

Gene tree reconstruction of the unique mitochondrial haplotypes was performed using Bayesian inference (BI), as implemented in MrBAyEs 3.2 (Ronquist et al. 2012). We used the nst=mixed option such that model uncertainty is taken into account during the phylogenetic reconstruction, and incorporated rate variation using the gamma setting. Four Metropolis-coupled MCMC chains (one cold and three heated) were run for $10 \times 10^{6}$ iterations with trees sampled every $10^{3}$ iterations.

We used PHASE v2.1.1 (Stephens et al. 2001), as implemented in DNASP 5.0 (Librado and Rozas 2009), to infer the alleles for the two nuclear loci (TGFb2 and MUSK) sequenced by Mahood et al. (2013). We used the recombination model and ran the iterations of the final run 10 times longer than for the initial runs. We considered the output of the long final PHASE run as the best estimate of haplotypes. We used TCS 1.21 (Clement et al. 2000) to reconstruct a $95 \%$ statistical parsimony network for two nuclear loci.

We used a Bayesian implementation of the general mixed Yule-coalescent model (bGMYC 1.0; Reid and Carstens 2012) to delimit species with our molecular data (speciation probability smaller than 0.05 ). This implementation incorporates gene tree uncertainty by sampling over the posterior distribution of sampled gene trees. We obtained a posterior distribution of ultrametric gene trees of the unique Orthotomus haplotypes using BEAST v1.8 (Drummond and Rambaut 2007) under GTR + G model, a strict clock model and a Yule process for the tree model. We calibrated the tree by using the ND2 rate estimated by Lerner et al. (2011). We ran MCMC for $10^{7}$ iterations with sampling of parameters and trees every $10^{3}$ iterations. The first $10 \%$ of the samples were removed as the burnin period. We analysed 100 trees sampled randomly from the posterior distribution and used the default setting in bGMYC. We ran the MCMC chains for $5 \times 10^{4}$ iterations, with a burn-in of $4 \times 10^{4}$ iterations, and sampled parameters every one hundred iterations. All taxa that are not part of Orthotomus were pruned from the ultrametric trees prior the BGMYC analyses.

\section{Biometry}

Measurements were taken on specimens housed in the MNHN and the Swedish Museum of Natural History (NRM) from O. sericeus $(n=12)$, O. atrogularis $(n=50)$, $O$. ruficeps $(n=23)$ and $O$. sepium $(n=10)$ for five characters: culmen length (to skull insertion), bill width at posterior edge of nostril, bill height at posterior edge of nostril, tarsus length (both sides) and wing chord (both sides). All measurements were taken by JF using a wingrule (measurements to the nearest $0.5 \mathrm{~mm}$ ) and a caliper (measurements to the nearest $0.1 \mathrm{~mm}$ ) (data available in Additional file 1: Table S2). The average measurement was taken for the tarsus length and the longest measurement was taken for the wing length for the further analyses. We performed a principal component analysis in $\mathrm{R}$, using the prcomp function, on all taxa. We also estimated the culmen length/wing length ratio to compare our results with those of Mahood et al. (2013).

\section{Results \\ Molecular data}

We obtained the entire ND2 sequences for all Orthotomus specimens (Fig. 2). The Bayesian Inference ND2 tree of the 66 unique Orthotomus haplotypes (107 individuals) yielded a tree with congruent topology to those previously reported by Sheldon et al. (2012) and Mahood et al. (2013). Among the five Vietnamese individuals of O. ruficeps, we identified two haplotypes (differing by 2 transitions) that were sister to the two other O. ruficeps (O. ruficeps borneoensis and O. ruficeps cineraceus) subspecies, although these relationships were not strongly supported (Posterior probabilities PP: 0.75). The uncorrected genetic distances between the Vietnamese O. ruficeps and O. ruficeps borneoensis and O. ruficeps cineraceus were $1.7 \%$ and $1.3 \%$, respectively. These genetic distances are similar to the one observed between O. ruficeps borneoensis and O. ruficeps cineraceus (1.3\%). The sister-species relationship between $O$. ruficeps ssp. and O. sepium was strongly supported (PP: 1.0). O. chaktomuk was nested within O. atrogularis, the two taxa forming a strongly supported clade (PP: 1.0). Among the four newly sequenced O. atrogularis individuals, MNHN ZO 1989-120, collected in Trang (Southern-Thailand), clustered with the individual collected in Singapore (PP: 0.75). The relationships of $O$. a. nitidus MNHN ZO 1882-728, 'Cochinchina', were unresolved whereas O. a. nitidus MNHN ZO 1929-1463, collected in Phu-Qui, and MNHN ZO 1939-913, collected in Hoi Xuan (northern Vietnam), were sister to part of the clade that includes all O. chaktomuk individual (PP: 0.96). Genetic distance between O. a. nitidus MNHN ZO 1929-1463/ZO 1939-913 and O. chaktomuk was 0.4-0.7\%.

The allele network for the two nuclear loci sequenced by Mahood et al. (2013) indicated extensive sharing of alleles among O. ruficeps, O. chaktomuk and O. a. atrogularis for TGFb2 and sorted, but intermingled haplotypes, for MUSK (Additional file 2: Fig. S1), suggesting that the three taxa could not be differentiated using these two loci. 


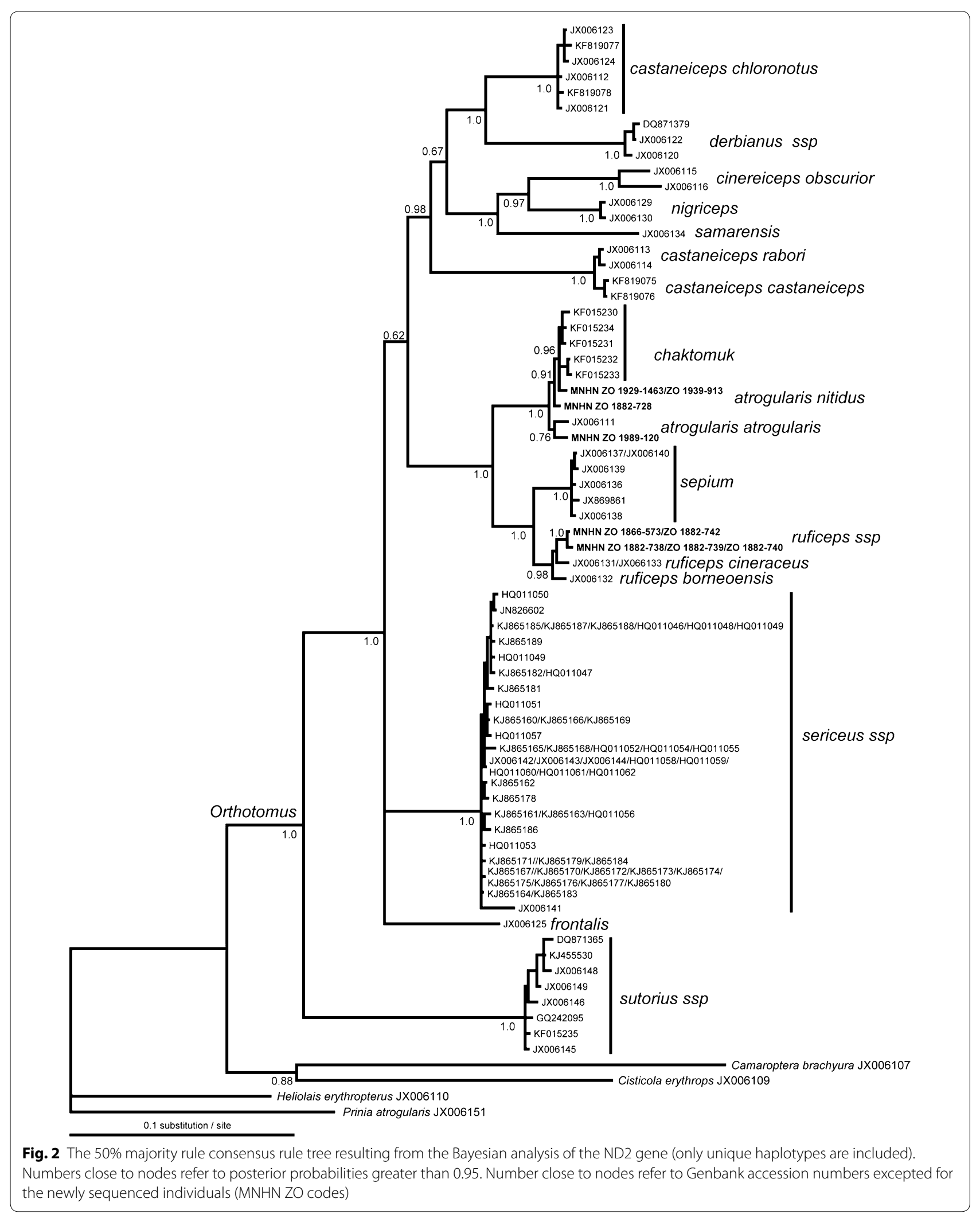


Results from the molecular species delimitations methods indicate that eleven species could be recognized in Orthotomus, as opposed to the thirteen recently proposed (Sheldon et al. 2012; Mahood et al. 2013; Additional file 2: Fig. S2). This estimate is possibly an underestimate as O. sepium and O. ruficeps, two undisputed species, were considered conspecific (speciation probability: 0.55; average uncorrected percent ND2 distances: 3.2\%; Sheldon et al. 2012). O. chaktomuk and O. atrogularis were considered conspecific (speciation probability: 0.77) as were all O. ruficeps individuals (speciation probability: 0.90-0.91).

\section{Biometric data}

The boxplots indicated that the three analysed $O$. ruficeps lineages could be distinguished from each other based on bill height. O. r. borneoensis could be further distinguished from continental populations based on culmen length, and the Cambodian/Vietnamese population could be distinguished from the two other lineages based on bill width (Table 3, Fig. 3). Tarsus and wing lengths do not allow discriminating between the different taxa. The boxplots of the culmen/wing ratio indicated that the Vietnamese O. ruficeps had the lowest ratio of all analysed taxa, whereas O. a. atrogularis had the highest (Fig. 3).

Results from the Primary Component Analysis indicated that the O. ruficeps collected in Vietnam could be discretely differentiated from individuals collected in Borneo (O. r. borneoensis) and Malay Peninsula (O. r. cineraceus) (Fig. 4). Most O. ruficeps subspecies could be separated on Axis 2. No differentiations could be made between the two O. atrogularis taxa (Fig. 4).

\section{Discussion}

\section{Re-discovered Ashy Tailorbird population}

Our analyses include for the first time individuals from a recently re-discovered allopatric population of Ashy Tailord (O. ruficeps) in SE Cambodia and Vietnam and highlighted the existence of discrete genetic and biometric characters when compared to other O. ruficeps populations. This population of Ashy Tailord (O. ruficeps) from SE Cambodia and Vietnam is between $500 \mathrm{~km}$ (assuming oversea dispersal) or $1000 \mathrm{~km}$ (assuming no over sea dispersal) from closest populations. This large geographic distance, coupled to the inferred poor dispersal capability of tailorbirds (small rounded wings) as well as the genetic and biometric differences, suggests that the Cambodian/Vietnamese population constitutes an isolated population and an independent evolutionary lineage worth of description. We consider that the subspecies we could not sample (O. r. ruficeps, Java; O. r. baeus, Nias and Pagi Is.; O. $r$. concinnus, Siberut, Sipura Is.; O. $r$. palliolatus, Kangean, Karimon Java Is.; O. r. baweanus, Bawean Is.; O. r. cagayanensis, Cagayan Sulu Is.) are highly unlikely

Table 3 Average/standard deviation and minimum-maximum values for six biometric characters for Orthotomus lineages

\begin{tabular}{|c|c|c|c|c|c|c|}
\hline Lineage & Culmen length (mm) & Bill width (mm) & Bill height (mm) & Tarsus length (mm) & Wing chord (mm) & $\begin{array}{l}\text { Culmen length/wing } \\
\text { chord }\end{array}$ \\
\hline r.borneonensis & $\begin{array}{l}17.55 / 0.62(16.4-18.3) \\
(n=8)\end{array}$ & $\begin{array}{l}2.65 / 0.26(2.3-3.0) \\
(n=8)\end{array}$ & $\begin{array}{l}2.59 / 0.08(2.5-2.7) \\
(n=8)\end{array}$ & $\begin{array}{l}19.18 / 0.95(17.9-20.85) \\
(n=8)\end{array}$ & $\begin{array}{l}47.44 / 1.8(45-50.5) \\
(n=8)\end{array}$ & $\begin{array}{l}0.37 / 0.022(0.34-0.40) \\
(n=8)\end{array}$ \\
\hline r. cineraceus & $\begin{array}{l}16.87 / 0.51(16.2-17.6) \\
(n=9)\end{array}$ & $\begin{array}{l}2.74 / 0.16(2.5-3.0) \\
(n=10)\end{array}$ & $\begin{array}{l}2.62 / 0.16(2.4-2.9) \\
(n=10)\end{array}$ & $\begin{array}{l}19.06 / 0.66(17.95-19.8) \\
(n=7)\end{array}$ & $\begin{array}{l}48.0 / 2.70(43-51) \\
(n=9)\end{array}$ & $\begin{array}{l}0.35 / 0.017(0.34-0.38) \\
(n=8)\end{array}$ \\
\hline r. 'ssp.' & $\begin{array}{l}16.38 / 0.76(15.6-17.6) \\
(n=5)\end{array}$ & $\begin{array}{l}3.02 / 0.04(3.0-3.1) \\
(n=5)\end{array}$ & $\begin{array}{l}2.98 / 0.15(2.8-3.2) \\
(n=5)\end{array}$ & $\begin{array}{l}18.6 / 0.58(17.85-19.35) \\
(n=5)\end{array}$ & $\begin{array}{l}49.5 / 2.57(46-53) \\
(n=5)\end{array}$ & $\begin{array}{l}0.33 / 0.011(0.32-0.35) \\
(n=5)\end{array}$ \\
\hline a. atrogularis & $\begin{array}{l}16.92 / 0.62(16.2-17.7) \\
(n=6)\end{array}$ & $\begin{array}{l}2.62 / 0.16(2.4-2.8) \\
(n=6)\end{array}$ & $\begin{array}{l}2.42 / 0.12(2.2-2.5) \\
(n=6)\end{array}$ & $\begin{array}{l}18.68 / 0.21(18.4-18.9) \\
(n=5)\end{array}$ & $\begin{array}{l}43.42 / 1.72(41-46) \\
(n=6)\end{array}$ & $\begin{array}{l}0.39 / 0.02(0.36-0.41) \\
(n=6)\end{array}$ \\
\hline a. nitidus & $\begin{array}{l}16.56 / 0.60(15.3-17.8) \\
(n=40)\end{array}$ & $\begin{array}{l}2.63 / 0.17(2.3-3.0) \\
(n=41)\end{array}$ & $\begin{array}{l}2.57 / 0.19(2.2-3.2) \\
(n=41)\end{array}$ & $\begin{array}{l}18.73 / 0.65(17.5-19.9) \\
(n=42)\end{array}$ & $\begin{array}{l}43.84 / 1.85(40-48) \\
(n=44)\end{array}$ & $\begin{array}{l}0.38 / 0.018(0.34-0.41) \\
(n=40)\end{array}$ \\
\hline s. sepium & $\begin{array}{l}16.78 / 1.10(14.5-17.9) \\
(n=10)\end{array}$ & $\begin{array}{l}2.65 / 0.35(2.3-3.4) \\
(n=10)\end{array}$ & $\begin{array}{l}2.57 / 0.19(2.2-2.9) \\
(n=10)\end{array}$ & $\begin{array}{l}18.92 / 0.69(17.55-20) \\
(n=10)\end{array}$ & $\begin{array}{l}45.65 / 1.80(41-47) \\
(n=10)\end{array}$ & $\begin{array}{l}0.37 / 0.03(0.31-0.41) \\
(n=10)\end{array}$ \\
\hline s. hesperius & $\begin{array}{l}19.9 / 0.95(18.8-20.5) \\
(n=3)\end{array}$ & $\begin{array}{l}2.97 / 0.15(2.8-3.1) \\
(n=3)\end{array}$ & $\begin{array}{l}3.0 / 0.15(2.9-3.2) \\
(n=3)\end{array}$ & $\begin{array}{l}21.25 / 0.49(20.9-21.6) \\
(n=2)\end{array}$ & $\begin{array}{l}53.0 / 3.0(50-56) \\
(n=3)\end{array}$ & $\begin{array}{l}0.38 / 0.03(0.355-0.376) \\
(n=3)\end{array}$ \\
\hline s. sericeus & $\begin{array}{l}19.08 / 0.57(18.3-20.1) \\
(n=8)\end{array}$ & $\begin{array}{l}3.16 / 0.26(2.6-3.1) \\
(n=7)\end{array}$ & $\begin{array}{l}2.98 / 0.25(2.6-3.2) \\
(n=5)\end{array}$ & $\begin{array}{l}21.1 / 1.04(19.6-22.3) \\
(n=9)\end{array}$ & $\begin{array}{l}51.94 / 2.88(47.5-55) \\
(n=9)\end{array}$ & $\begin{array}{l}0.365 / 0.018(0.34-0.40) \\
(n=8)\end{array}$ \\
\hline derbianus & $\begin{array}{l}19.1 \\
(n=1)\end{array}$ & $\begin{array}{l}3.0 \\
(n=1)\end{array}$ & $\begin{array}{l}3.2 \\
(n=1)\end{array}$ & $\begin{array}{l}20.4 \\
(n=1)\end{array}$ & $\begin{array}{l}50 \\
(n=1)\end{array}$ & $\begin{array}{l}0.38 \\
(n=1)\end{array}$ \\
\hline
\end{tabular}

The morphological characters are culmen length, bill width at nostril, bill height at nostril, tarsus length (average of the left and right tarsus when possible) and wing chord (longest measurement of the left or ring wing). All characters but wing length were measured to the nearest $0.1 \mathrm{~mm}$. Wing length was measured to the nearest $0.5 \mathrm{~mm}$ 

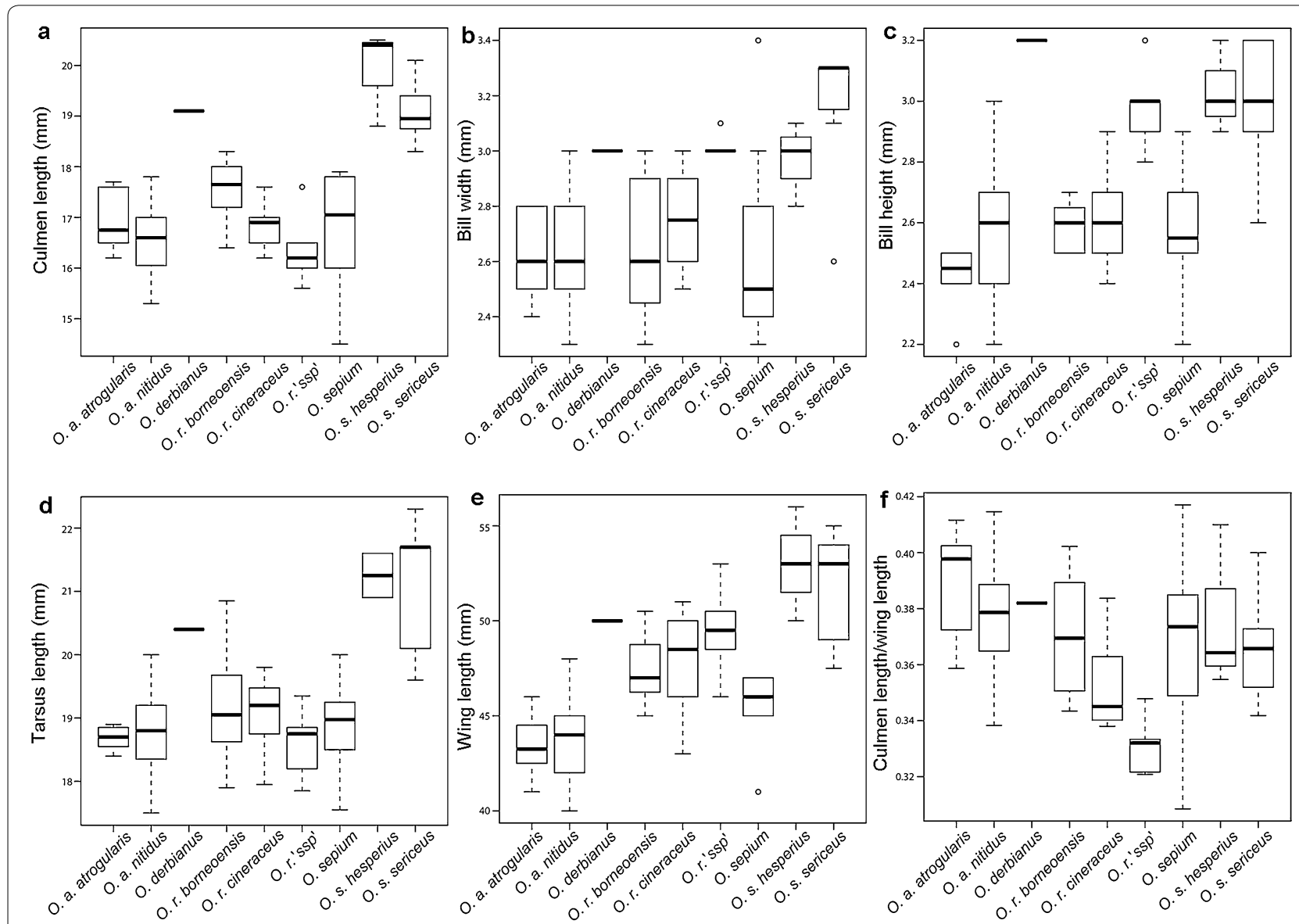

Fig. 3 Boxplots of the five morphological characters (a-e) and culmen length/wing length ratio (f) measured for the primary lineages from the 0 . atrogularis ssp., O. ruficeps ssp., O. sericeus ssp., O. sepium and O. derbianus taxa (data in Additional file 1: Table S2)

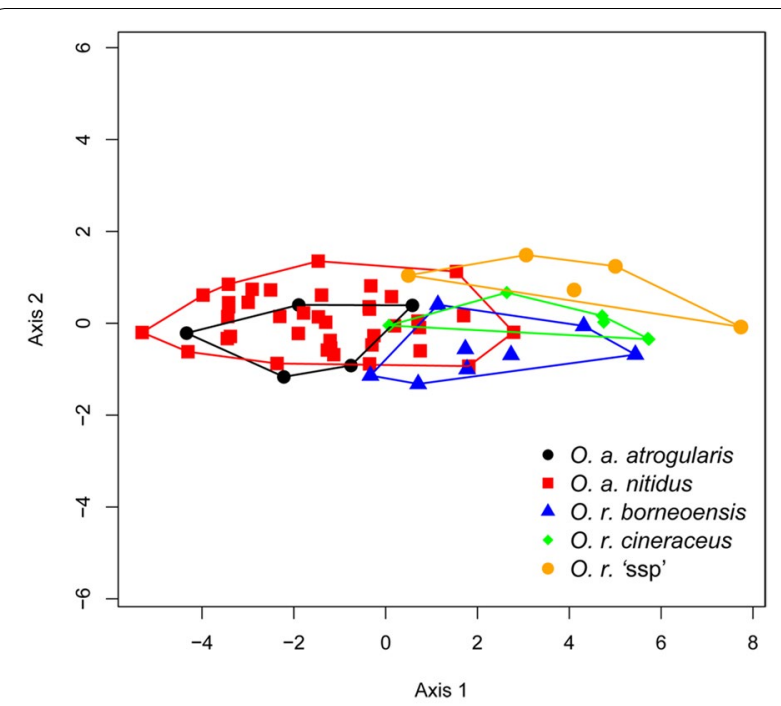

Fig. 4 Plot of the axes 1 and 2 of the Principal Component Analysis (PCA) for the O. ruficeps and O. atrogularis subspecies based on the analyses of culmen length, bill width, bill height, tarsus length and wing length to be more closely related to the Cambodian/Vietnam populations than populations from continental Southeast Asia based on described phylogenetic patterns (e.g. Sheldon et al. 2009; Lim et al. 2014; Fuchs et al. 2015).

Based on the phylogenetic pattern, biometrics differences and distribution data, we recognize a new subspecies for the Orthotomus population distributed in Southern Vietnam and Cambodia that we name "O. ruficeps germaini Fuchs Zuccon subsp. nov".

\section{Holotype}

Adult Female Muséum National d'Histoire Naturelle, Paris MNHN ZO-1882-739. Collected by Louis Rodolphe Germain on the 21 April 1865 in 'Cochinchina', corresponding now to southern Vietnam.

\section{Diagnosis}

Based on available specimens, the Ashy Tailorbird subspecies from Vietnam could not be diagnosed by plumage characters from other Ashy Tailorbird subspecies we examined. 
Madge (2018) mentioned that O. r. borneoensis has a slightly darker head than $O$. cineraceus and that subspecies differs by the darkness of on the upperparts but we could not recover this trend on the specimens we examined. As for other $O$. ruficeps subspecies, there is sexual dimorphism in O. ruficeps: males have a tawny chin and grey throat whereas females have a white chin and throat washed with gray. One male (MNHN ZO 1882-738) has white streaks on throat suggesting that it could be a first-year bird. The new taxon could be diagnosed by culmen length, bill height from other O. ruficeps subspecies and by plumage, bill width, and wing length from the sympatric O. atrogularis (Fig. 5). The new subspecies differs from the recently described and possibly parapatric $O$. chaktomuk by cheeks and thighs colours (Mahood et al. 2013). A genetic divergence of $1 \%$ from O. $r$. cineraceus and 1.1-1.3\% from O. r. borneoensis was recovered at the analysed mitochondrial locus.

\section{Description of holotype}

We used the colour designations from Smithe (1975; corresponding number in parentheses) when relevant. Forehead, lores, ear-coverts and legs TAWNY (38), rectrices, primaries, secondaries, crown and nape CINNAMON BROWN (33) back and rump DARCK NEUTRAL GRAY (83), flanks and sides LIGHT NEUTRAL GRAY (85) chin, throat, and abdomen white and washed with MEDIUM NEUTRAL GRAY (84). The mitochondrial ND2 locus was sequenced for the holotype (Genbank Accession Number MH507592).

\section{Measurements of holotype}

Left/right tarsus: $18.1 / 18.3 \mathrm{~mm}$, left/right wing-chord: 50.5/50 mm, culmen length: $16.2 \mathrm{~mm}$, bill-width at anterior end of nostril $3.0 \mathrm{~mm}$, bill-depth at anterior end of nostril $3.0 \mathrm{~mm}$.

\section{Paratype. MNHN ZO 1866-573 (Fig. 6)}

Adult female collected by Louis Rodolphe Germain (collector number 170) on the 28 February 1864 in 'Cochinchina', corresponding now to southern Vietnam. Measurements: left/right tarsus: $17.7 / 18.0 \mathrm{~mm}$, left/ right wing-chord: $46 / 46 \mathrm{~mm}$, culmen length: $16.0 \mathrm{~mm}$, bill-width at anterior end of nostril $3.0 \mathrm{~mm}$, bill-depth at anterior end of nostril $2.9 \mathrm{~mm}$. The mitochondrial sequence of ND2 of the paratype MNHN ZO 1866-573 (Genbank Accession Number: MH507590) differs by two substitutions from that of the holotype.

\section{Paratype. MNHN ZO 1882-742}

Adult male collected by Louis Rodolphe Germain (collector number 170) on the 29 February 1864 in 'Cochinchina', corresponding now to southern Vietnam. Measurements: left/right tarsus: 19.2/19.5.0 mm, left/ right wing-chord: $53 / 52 \mathrm{~mm}$, culmen length: $17.6 \mathrm{~mm}$, bill-width at anterior end of nostril $3.0 \mathrm{~mm}$, bill-depth at anterior end of nostril $3.2 \mathrm{~mm}$. The mitochondrial sequence of ND2 of the paratype MNHN ZO 1882-742 (Genbank Accession Number: MH507594) differs by two substitutions from that of the holotype and is identical to that of the paratype MNHN ZO-1866-573.

\section{Etymology}

We dedicate this subspecies to the initial collector Louis Rodolphe Germain (1827-1917), a veterinary surgeon in the French colonial's army during the $1860-1865$ period, in 'Cochinchina. He made important zoological collections in Vietnam and later in New Caledonia, including new species of birds (Germain's Peacock-Pheasant Polyplectron germaini, Germain's Swiftlet Aerodramus germani) and mammals (Indochinese Lutung Trachypithecus germaini).
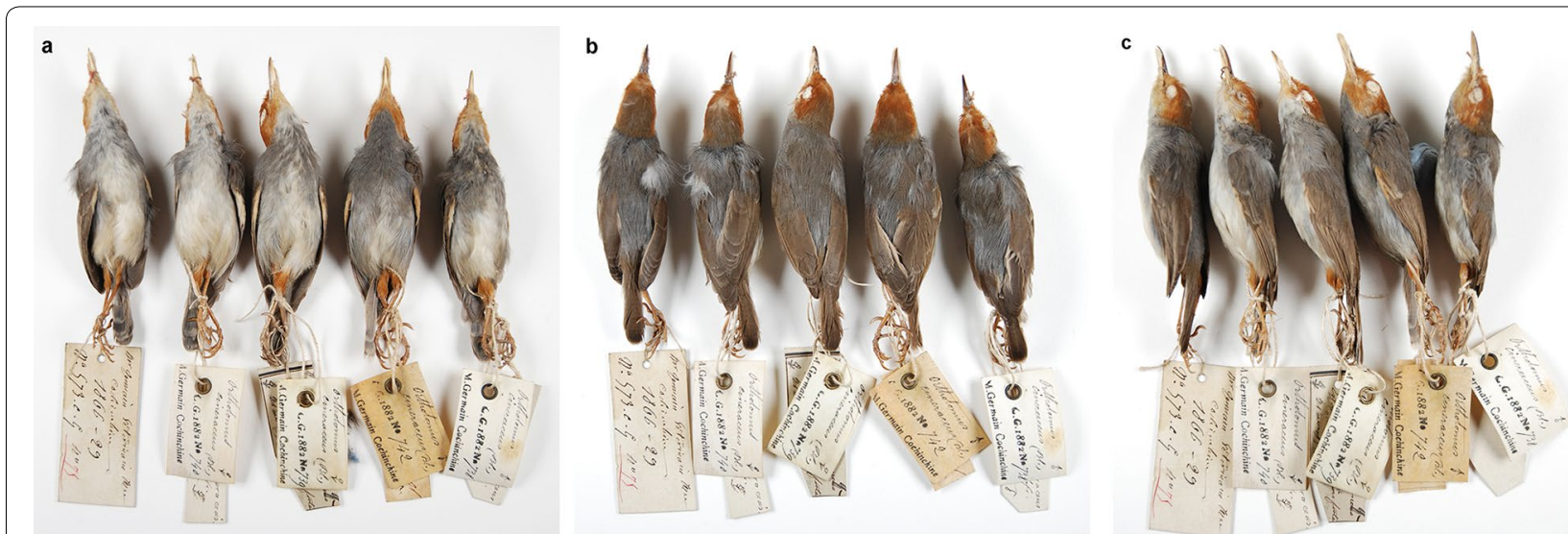

Fig. 5 Photos of the five specimens held at MNHN in ventral (a), dorsal (b) and lateral (c) views. From left to right. MNHN ZO $1966-573$ (paratype), MNHN ZO 1938-738, MNHN ZO 1938-739 (holotype), MNHN ZO 1938-740, MNHN ZO 1938-742 (paratype) 

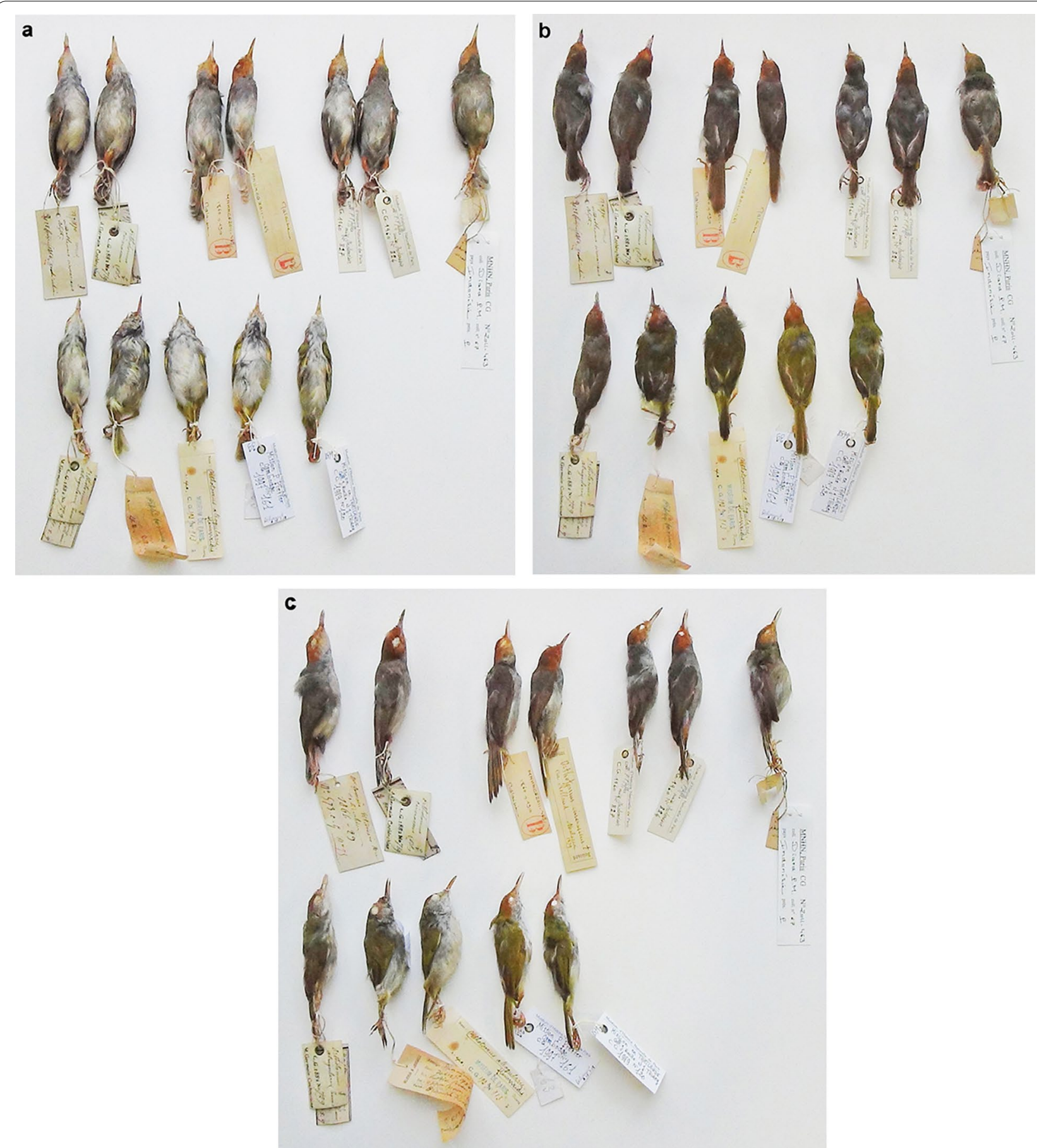

Fig. 6 Comparisons of O. r. germaini with other Orthotomus taxa in ventral (a), dorsal (b), and lateral (c) views. Upper specimens (from left to right) O. r. germaini MNHN-ZO 1866-573 (paratype), MNHN-1882-739 (holotype); O. r. cineraceus MNHN ZO-1881-518, MNHN ZO-2011-465; O. r. borneoensis MNHN-ZO 1860-827, MNHN ZO-1860-824; O. sepium MNHN-ZO 2011-463. Lower specimens (from left to right): O. a. nitidus MNHN-ZO 1882-728, MNHN-ZO 1929-1463, MNHN-ZO 1939-913, MNHN-ZO 1997-161; O. a. atrogularis MNHN-ZO 1989-120

Other specimens examined and not part of the type-serie Three other specimens are known for O. r. germaini: MNHN ZO 1882-738 and MNHN ZO 1882-740 all collected by Louis Rodolphe Germain in 'Cochinchina'. One further specimen 'MNHN ZO 1882-741' was part of a set of 88 specimens donated to Hans von Berlepsch in 
1892 by the MNHN. This specimen is now in the Senckenberg Museum (Frankfurt am Main, SMF 78404).

\section{Vocalisations}

We only found one vocalization on Xeno-Canto (http:// www.xeno-canto.org/) that could apply to O. r. germaini, a call (XC306137) from Cái Bè, Tiền Giang, Vietnam (Latitude: $10.3282^{\circ}$, Longitude: $105.9659^{\circ}, 24$ January 2016) collected by Nick Talbot.

\section{Distribution and conservation}

This new subspecies appears to be restricted to Southern Vietnam (specimen data, vocalisations) and possibly south-east Cambodia (Goes 2013; Mahood et al. 2013; Mahood and Martin 2013). Southern Vietnam and Cambodia hold several mangroves that are under threat and recognition of this population as an endemic taxon could enhance conservation plans and understand macroecological patterns of biodiversity. Clearly, thorough inventories of these areas are crucial to understand in more details the distribution of $O$. ruficeps germaini.

\section{Nomenclatural acts}

The electronic edition of this article conforms to the requirements of the amended International Code of Zoological Nomenclature (International Commission on Zoological Nomenclature 1999), and hence the new name contained herein is available under that Code from the electronic edition of this article. This published work and the nomenclatural act it contains have been registered in ZooBank with the ZooBank Life Science Identifier urn:Isid:zoobank.org:pub:0D7F54E5-F4674D43-8404-A936F644279E. The electronic edition of this work was published in a journal with ISSN 2053-7166, and has been archived and is available from the digital repository http://www.ncbi.nlm.nih.gov/pmc/.

\section{What is the Cambodian Tailorbird?}

Our analyses revealed that the Cambodian Tailorbird haplotypes are nested within $O$. a. atrogularis. Noticeably, the genetic divergence between $O$. chaktomuk and O. atrogularis is now $0.7 \%$, as opposed to the initial $1.4 \%$ in the initial species description (no O. a. nitidus were included in the original genetic analyses; Mahood et al. 2013). This genetic distance is lower than the genetic divergence observed among populations of the White-rumped Shama (Copsychus saularis) distributed in Singapore and China (Sheldon et al. 2009). The Cambodian Tailord is barely distinguishable from O. nitidus atrogularis or O. ruficeps cineraceus species based on biometric data although culmen/wing ratio was slightly lower (Mahood et al. 2013). The Cambodian/Vietnamese O. ruficeps population has the lowest culmen wing ratio in our biometric data. The most distinctive O. chaktomuk feature is its plumage which is, in fact, intermediate between O. atrogularis and O. ruficeps. O. ruficeps germaini currently inhabits the Mekong area of Vietnam (Buckton and Safford 2004; Robson 2011) whereas $O$. chaktomuk inhabits evergreen dense scrubs of the Mekong and Tonle Sap floodplain that is just further north on the same floodplain system. Hence, we here hypothesize that $O$. chaktomuk could refer to a hybrid population, not necessarily first generation between $O$. ruficeps germaini and $O$. atrogularis nitidus. If this hypothesis is correct, then from the current data available, hybridization is or was possibly asymmetrical as the mitochondrial DNA is always 'atrogularis like' or particular combinations of backcrosses are not viable or fertile. In favor of this hypothesis is the intermediate plumage and somewhat intermediate culmen/wing ratio where the O. chaktomuk culmen/wing ratio is intermediate and closer to O. atrogularis, and the restricted distribution of O. chaktomuk. We notice that our ratios for all taxa are slightly different than those reported by Mahood et al. (2013) and we attribute the differences to the operator effect. Evolutionary implications for this putative hybrid zone could either be a stable hybrid or tension zone or despeciation process where non-differentiated taxa remerge (e.g. Phoenicurus phoenicurus, Corvus corax; Webb et al. 2011; Hogner et al. 2012). Alternatively, O. chaktomuk could represent a very recent offshoot of O. atrogularis that differentiated very recently and not enough time passed for the mtDNA to coalesce. This scenario is also possible as genetic distances are not always indicative of reproductive isolation. Yet, the molecular species delimitation method is a good approximation of the number of Orthotomus species recognized in previous studies with dense sampling (Sheldon et al. 2012; Lim et al. 2014). The only exception implies the species pair O. ruficeps/O. sepium, which have a limited genetic divergence (3.2\%, Sheldon et al. 2012) but their speciation probability was only 0.55 . In contrast, the probability that $O$. chaktomuk was distinct at the species-level from the $O$. atrogularis was much lower (speciation probability 0.77 ). The limited nuclear data available do not allow favoring or rejecting any of the hypotheses as they are lacking for the two taxa that would be involved in the hybridization $(O$. atrogularis nitidus and O. ruficeps germaini). Furthermore, the fact that all these taxa are closely related may result in the fact that most taxa would not be monophyletic in the nuclear loci or hold distinctive substitutions that could detect hybrids with few intronic loci. Hence further individuals and genomic approaches using the isolation with migration model may be needed to resolve the question. If O. chaktomuk indeed represents a distinct taxon, its interaction from a genetic point of view with its sympatric $(O$. atrogularis nitidus) or parapatric (O. ruficeps germaini) should be further studied. 
From a conservation point of view, we argue that the fact that whether O. chaktomuk constitutes a 'good' species or in fact refers to a hybrid population should have no impact. Indeed, the area where O. chaktomuk occurs should be protected either to preserve the patterns of evolution (species) and/or the underlying processes (speciation or hybridization).

\section{Conclusion}

Our analyses characterized the biometric and molecular distinctiveness of a recently re-discovered population of Ashy Tailord in SE Cambodia and Vietnam. These diagnosable differences, coupled to a strict allopatric distribution with other $O$. ruficeps populations distributed in South-east Asia suggest that the Cambodian/Vietnamese population constitutes an independent evolutionary lineage worth of description. Concerning the Cambodian Tailorbird, our analyses revealed that this species is in fact nested within the Dark-necked Tailorbird and that the genetic divergence is much lower than initially described. Because of its phylogenetic position, intermediate biometry, plumage and distribution when compared to O. a. nitidus and the Cambodian/Vietnamese population of O. ruficeps, we hypothesize that the name O. chaktomuk refers to a hybrid population, hybrid swarm or the results of the introgression between $O$. a. nitidus and $O$. ruficeps and is not a valid species. Final confirmation of this hypothesis would nevertheless need the analyses of more individuals and genome scale data.

\section{Additional files}

Additional file 1: Table S1. Primer pairs used in the amplification and sequencing of the ND2 gene. Table S2. Measurement details for the specimens included in the biometric analyses.

Additional file 2: Figure $\mathbf{S 1 . 9 5 \% ~ s t a t i s t i c a l ~ p a r s i m o n y ~ n e t w o r k ~ o b t a i n e d ~}$ for the TGFb2 and MUSK loci. Black dots represent unsampled or extinct haplotypes. Circle size is proportional to haplotype frequency. Colour codes are: O. atrogularius (Blue), O. chaktomuk (green), O. r. borneoensis (yellow), O. r. cineraceus (orange). Figure S2. Summary of bGMYC species delimitation using the mitochondrial data set. The tree is the maximum clade credibility tree from BEAST within the Orthotomus tailorbirds. The heat map is a sequence-by-sequence matrix in which cells are coloured by the posterior probability such that the corresponding sequences are conspecific, with increasing probability represented by light yellow colours. The scale is given on the right of the tree. The analyses would support the recognition of eleven species within Orthotomus.

\section{Authors' contributions}

JF and DZ conceived the study, analysed the data and wrote the manuscript. JF collected the biometric data. DZ performed laboratory work. Both authors read and approved the final manuscript.

\section{Acknowledgements}

We are very grateful to U. Johansson (NRM) for access to the NRM collection and I. Bisang and E. Dock for help with the Synthesys grant. M. Päckert and G. Mayr provided information for the specimen housed at the Senckenberg
Museum. This work was supported by 'Service de Systématique Moléculaire' (UMS2700 Outils et Méthodes de la Systématique intégrative, MNHN). Help during laboratory work was kindly provided by C. Bonillo, D. Gey and J. Lambourdière (UMS2700, MNHN). P. Bousses (MNHN) provided the photos of the specimens.

\section{Competing interests}

The authors declare that they have no competing interests.

\section{Availability of data and materials}

Newly generated data have been deposited in Genbank (www.ncbi.nlm. nih.gov). Biometric data analysed in this study are listed in Supplementary Table 2 (Additional file 1: Table S2). All specimens examined and measured are deposited in the collection of the Muséum National d'Histoire Naturelle, Paris $(\mathrm{MNHN})$ and Swedish Museum of Natural History (NRM).

\section{Consent for publication}

Not applicable.

\section{Ethics approval and consent to participate}

No animals were captured and sampled by the authors as part of this study.

\section{Funding}

We acknowledge the support by a SYNTHESYs grant made available to J. Fuchs by the European Community-Research Infrastructure Action under the FP6 Structuring the European Research Area Program (SE-TAF-7153).

Received: 14 February 2018 Accepted: 10 September 2018

Published online: 25 September 2018

\section{References}

Buckton ST, Safford RJ. The avifauna of the Vietnamese Mekong Delta. Bird Conserv Int. 2004;14:279-322.

Clement M, Posada D, Crandall KA. TCS: a computer program to estimate gene genealogies. Mol Ecol. 2000;9:1657-9.

Dickinson EC, Christidis L. The Howard and Moore complete checklist of the birds of the world, vol. 2. 4th ed. Eastbourne: Aves Press; 2014.

Drummond AJ, Rambaut A. BEAST: Bayesian evolutionary analysis by sampling trees. BMC Evol Biol. 2007;7:214.

Fuchs J, Ericson PGP, Bonillo C, Couloux A, Pasquet E. The complex phylogeography of the Indo-Malayan Alophoixus bulbuls with the description of a putative new ring species. Mol Ecol. 2015;24:5460-74.

Fuchs J, Pasquet E, Stuart BL, Woxvold I, Duckworth JW, Bowie RCK. Phylogenetic affinities of the enigmatic Bare-faced Bulbul Pycnonotus hualon with description of a new genus. Ibis. 2018;160:659-65.

Goes F. The birds of Cambodia: an annotated checklist. Cambodia: Centre for Biodiversity Conservation, Fauna \& Flora International Cambodia Programme and Royal University of Phnom Penh; 2013.

Hogner S, Laskemoen T, Lifjeld JT, Porkert J, Kleven O, AlbayrakT, Kabasakal B, Johnsen A. Deep sympatric mitochondrial divergence without reproductive isolation in the common redstart Phoenicurus phoenicurus. Ecol Evol. 2012;2:2974-88.

ICZN. International Code of Zoological Nomenclature. 4th edn, London: The International Trust for Zoological Nomenclature; 1999. p. 1-29, 1-306.

Jenkins JD, Kilpatrick CW, Robinson MF, Timmins RJ. Morphological and molecular investigations of a new family, genus and species of rodent (Mammalia: Rodentia: Hystricognatha) from Lao PDR. Syst Biodivers. 2005;2:419-54.

Lerner HRL, Meyer M, James HF, Hofreiter M, Fleischer RC. Multilocus resolution of phylogeny and timescale in the extant adaptive radiation of Hawaiian Honeycreepers. Curr Biol. 2011;21:1838-44.

Librado P, Rozas J. DnaSP v5: a software for comprehensive analysis of DNA polymorphism data. Bioinformatics. 2009;25:1451-2.

Lim HC, Chua VL, Benham PM, Oliveros CH, Rahman MA, Moyle RG, Sheldon FH. Divergence history of the Rufous-tailed Tailorbird (Orthotomus sericeus) of Sundaland: implications for the biogeography of Palawan and the taxonomy of island species in general. Auk. 2014;131:629-42. 
Madge S. Ashy Tailorbird (Orthotomus ruficeps). In: del Hoyo J, Elliott A, Sargatal $J$, Christie DA, de Juana E, editors. Handbook of the birds of the world alive. Barcelona: Lynx Edicions; 2018.

Mahood SP, Martin RW. Ashy Tailorbird Orthotomus ruficeps: the first records for Cambodia. Bird Asia. 2013;19:121-2.

Mahood SP, John AJl, Eames JC, Oliveros CH, Moyle RG, Hong C, Poole CM, Nielsen $\mathrm{H}$, Sheldon $\mathrm{FH}$. A new species of lowland tailorbird (Passeriformes: Cisticolidae: Orthotomus) from the Mekong floodplain of Cambodia. Forktail. 2013:29:1-14.

Reid NM, Carstens BC. Phylogenetic estimation error can decrease the accuracy of species delimitation: a Bayesian implementation of the general mixed Yule-coalescent model. BMC Evol Biol. 2012;12:196.

Robson CR. A field guide to the birds of South-east Asia. London: New Holland; 2011.

Ronquist F, Teslenko M, van der Mark P, Ayres D, Darling A, Höhna S, Larget B, Liu L, Suchard MA, Huelsenbeck JP. MrBayes 3.2: efficient Bayesian phylogenetic inference and model choice across a large model space. Syst Biol. 2012;61:539-42.

Sheldon FH, Lohman DJ, Lim HC, Zou F, Goodman SM, Prawiradilaga DM, Winker K, Braile TM, Moyle RG. Phylogeography of the magpie-robin species complex (Aves: Turdidae: Copsychus) reveals a Philippine species, an interesting isolating barrier and unusual dispersal patterns in the Indian Ocean and Southeast Asia. J Biogeogr. 2009;36:1070-83.
Sheldon FH, Oliveros CH, Taylor SS, McKay B, Lim HC, Rahman MA, Mays H, Moyle RG. Molecular phylogeny and insular biogeography of the lowland tailorbirds of Southeast Asia (Cisticolidae: Orthotomus). Mol Phylogenet Evol. 2012;65:54-63.

Smithe FB. Naturalist's color guide. New York: American Museum of Natural History; 1975.

Stephens M, Smith NJ, Donnelly P. A new statistical method for haplotype reconstruction from population data. Am J Hum Genet. 2001;68:978-89.

Stuart BL, Papenfuss TJ. A new salamander of the genus Paramesotriton (Caudata: Salamandridae) from Laos. J Herpetol. 2002;36:145-8.

Vu VD, Pham MG, Nguyen NC, Do T, Arctander P, MacKinnon J. A new species of living bovid from Vietnam. Nature. 1993;363:443-5.

Webb WC, Marzluff JM, Omland KE. Random interbreeding between cryptic lineages of the Common Raven: evidence for speciation in reverse. Mol Ecol. 2011;20:2390-402.

Woxvold IA, Duckworth JW, Timmins RJ. An unusual new bulbul (Passeriformes: Pycnonotidae) from the limestone karst of Lao PDR. Forktail. 2009;25:1-12.

Zuccon D, Ericson PGP. The phylogenetic position of the Black-collared Bulbul Neolestes torquatus. Ibis. 2010;152:386-92.
Ready to submit your research? Choose BMC and benefit from:

- fast, convenient online submission

- thorough peer review by experienced researchers in your field

- rapid publication on acceptance

- support for research data, including large and complex data types

- gold Open Access which fosters wider collaboration and increased citations

- maximum visibility for your research: over 100M website views per year

At BMC, research is always in progress.

Learn more biomedcentral.com/submissions 